\title{
Quality Assurance in an Academic Library Contact Center
}

by Nita Mailander

\section{INTRODUCTION}

As libraries have been transformed by virtual services and online learning, academic libraries are focusing on customer-driven services to support students, faculty, and staff. In his editorial "Distinctive Signifiers of Excellence: Library Services and the Future of the Academic Library," Walter $(2011,7)$ challenges librarians to "engage the question of what array of services our users should expect to find in a 21st-century academic library" and to include services, not just collections, in our discussions of "distinctive signifiers of excellence." Bell (2019), in his editorial in Library Journal, also challenges academic libraries to embrace the "customer-driven service culture." Today, every student, faculty, and staff member in higher education is potentially an online student, instructor, or telecommuter. Including quality assurance measures in the academic library contact center designed to meet library customer needs regardless of physical location is an effective, distinctive approach to providing library services.

\section{BACKGROUND}

Grand Canyon University (GCU) began in 1949 as Baptist-affiliated Prescott College, prior to moving to West Phoenix in 1951. In 1984, the College transitioned to Grand Canyon University and from being owned and operated by the Arizona Southern Baptist Convention to being self-owned by the Board of Trustees. In 2008, on the brink of bankruptcy, the university transitioned again to a forprofit institution with the help of capital from an initial public offering that allowed the university to continue operating. In 2018, the university transitioned back to its historical roots as a non-profit institution (GCU 2020). For the fall semester in 2019, the campus served more than 22,000 traditional students, and more than 80,000 online students (Larrison 2019).

The library staff growth has reflected the successful growth and transition of the university over time. In 2007, there were two professional librarians and one paraprofessional on the library staff. In 2010, with seven professional librarians and four paraprofessional staff, the GCU Library established a new model of centralized Ask-A-Librarian services to answer all questions regardless of subject and origin, providing virtual and face-to-face, on-demand individualized research assistance to students, faculty, and staff. The academic library contact center launched as a full virtual instruction and consultation service.

\section{LITERATURE REVIEW}

Although contact or call centers are discussed in the published literature in a variety of organizational settings, there is very limited discussion regarding the academic library contact center, much less continuous quality assurance programs for virtual library services. In their 2004 article "Call

Nita Mailander is Director of Library Services at Grand Canyon University. 
Centres for Enhanced Reference Services," Sattar Chaudhry and Jeanne identified Monash University Library and the New Brunswick Libraries of Rutgers University in New Jersey. Both academic call centers handled general inquiries and transferred any subject-specific inquiries to branches or specialists. Calls were generally expected to be resolved in five minutes and there was no mention of quality assurance measures. In 2006, Burke and Berenak wrote about the telephone enquiry service (TES) which was implemented at Bundoora Campus Library at La Trobe University in Australia which served the need "to answer in a central location those repetitive directional queries such as opening hours and queries about library holdings" (212). There was again no mention of quality assurance measures.

Likewise, there is literature discussing telephone reference in academic libraries, but very limited discussion of academic library contact centers. In 2009, Murphy published her findings regarding applying Six Sigma philosophy as an example of continuous quality improvement at the Ohio State University Libraries. The discussion regarding assessment and reference services continues with the case study "Implementing the Customer Contact Center," which describes the model that Ohio State University Libraries adopted. Murphy and Cerqua (2012) not only describe the centralized academic library services but also provide insight and detail into the quality assessment of calls recorded through their "Ask Us!" library services. They assert that "libraries that develop systems for monitoring and improving the quality of their interactions with customers can maintain their relevance" (299).

Brehm-Heeger et al.'s (2013) article "Library Call Centers" reviews public library call centers. Each of the five public libraries and library systems described had call centers that had a primary role for "redirecting calls from the public service desk" (33). Some of the call center staff also handled email and chat reference services when not providing phone service. Johnson County Library's call center in Kansas was identified as including a quality assessment program through the use and review of voice recording software, but no details were included.

\section{THE GCU LIBRARY CONTACT CENTER}

The GCU Library has a team of twenty-two librarians and seven paraprofessionals. Fourteen fulltime and three part-time librarians, along with five paraprofessionals and a team of student workers, staff the Ask-A-Librarian contact center through the in-person, phone, email, and chat service points. Staff are cross-trained to provide support for all the library's resources, regardless of subject matter or type of resource. On-demand customized research assistance is provided, including assisting with interlibrary loan requests, appointment scheduling, computer and media instruction, and answering and referring questions regarding the University's academic services and resources. The Ask-A-Librarian service is open for students, faculty, and staff ninety-nine hours per week.

Group library instruction is also a responsibility of librarians on the Ask-A-Librarian service team and the one-shot library instruction sessions are scheduled virtually or face-to-face as requested by faculty. The library also runs a robust webinar schedule of recurring virtual instruction sessions across twelve webinars, including such topics as library introduction, doctoral research, APA formatting, and more. The Ask-A-Librarian Service answered over 73,000 inquiries from July 2018 to June 2019, and the librarians taught 562 sessions with 13,955 attendees, with the mission to support and meet the needs of students, faculty, and staff where they are academically and geographically (Grand Canyon University Library 2019). 


\section{QUALITY ASSURANCE INITIATIVE}

In 2012, phone queue software was implemented in the GCU Library Ask-A-Librarian service to further provide efficient call flow and maximize customer service efforts. The library joined the ongoing university-wide QA initiative in 2018 with the launch of the recording and analysis of inbound and outbound phone calls to the Ask-A-Librarian service. The library's chat service was also added to the QA initiative in 2019.

The library's phone and chat QA initiatives measure eight areas of staff competency focused on customer service, including the following areas: opening, knowledge and understanding, communication, advising and problem solving, ownership, branding, and closing. Two inbound calls and one outbound call are evaluated each month for the librarians and student workers who answer phone calls for the Ask-A-Librarian service. Additionally, for the librarians who staff the chat service, three chat sessions are evaluated. Calls and chat sessions are graded by the university's quality assurance team evaluators and the evaluation results are accessible via a personal staff dashboard for each staff member and are reviewed by library department supervisors and managers who provide individualized feedback and coaching. Staff members reaching and maintaining one hundred percent compliance are recognized quarterly and become part of the university’s QA 100 Club.

\section{QUALITY ASSURANCE METRICS}

Since implementing the phone QA initiative in September 2018, over 42,000 phone calls were received by library staff through April 2020. For the Ask-A-Librarian chat service QA implemented in June 2019, over 4,000 chats were received by library staff through April 2020. As a result of these initiatives, 1,020 evaluations were completed resulting in an average departmental score of $98.55 \%$ percent (out of 100\%). This quality assurance model promotes and sustains a high level of customer service and supports an organizational culture of assessment and improvement across the library team.

\section{CONCLUSIONS}

The implementation of quality assurance to the GCU Library's Ask-A-Librarian service has strengthened the library's continuous improvement processes, enhancing the library's quality and overall effectiveness in providing academic support to students, faculty, and staff. Library staff, although initially cautious to embrace the new quality assurance model, have found great success and external confirmation of the quality, caring customer service provided. For library supervisors and managers, the quality assurance model has allowed a new level of norming, training, and accountability to high customer service standards across the library's in-person and virtual service points. By using a continuous quality improvement process coupled with centralized services and an emphasis on customer service with a servant's heart, the academic library contact center can provide a level of dynamic, distinctive services that demonstrate the library's value to the academic community. 


\section{WORKS CITED}

Bell, Steven. “Academic Librarians' C-Word Problem: From the Bell Tower.” Library Journal. Accessed May 27, 2020. www.libraryjournal.com/?detailStory=Academic-Librarians-C-WordProblem-From-the-Bell-Tower.

Brehm-Heeger, Paula, Monica Duffield, Sue Klinke, M. J. Howe, Cindy Phillips, and Barb WrightWisner. 2013. "Library Call Centers: Five Unique Examples.” Public Libraries 52, no. 1: 32-6. publiclibrariesonline.org/2014/01/library-call-centers.

Burke, Liz and Lea Beranek. 2006. "Call Us: Development of a Library Telephone Enquiry Service.” Australian Library Journal 55, no. 3: 211-23. doi.org/10.1080/00049670.2006.10721853.

Grand Canyon University. 2020. “History of GCU.” Accessed May 27, 2020. www.gcu.edu/why-gcu/ history-of-gcu.

Grand Canyon University Library. 2019. “About the GCU Library.” Accessed May 27, 2020. libguides. gcu.edu/AboutUs.

Larrison, Ashlee. 2019. "Another Record Year in Store for Grand Canyon University.” GCU Today. Accessed May 27, 2020. news.gcu.edu/2019/08/another-record-year-in-store-at-grand-canyonuniversity/.

Murphy, Sarah Anne. 2009. "Leveraging Lean Six Sigma to Culture, Nurture, and Sustain Assessment and Change in the Academic Library Environment." College \& Research Libraries 70, no. 3: 215-25. doi.org/10.5860/0700215.

Murphy, Sarah Anne and Judith Cerqua. 2012. "Implementing the Customer Contact Center: An Opportunity to Create a Valid Measurement System for Assessing and Improving a Library's Telephone Services.” Portal: Libraries and the Academy 12, no. 3: 299-314. dx.doi.org/10.1353/ pla.2012.0031.

Sattar Chaudhry, Abdus and Chua Jeanne. 2004. "Call Centres for Enhanced Reference Services: A Comparison of Selected Library Call Centres and the Reference Point at National Library of Singapore.” Library Review 53, no. 1: 37-49. doi.org/10.1108/00242530410514784.

Walter, Scott. 2011. "Distinctive Signifiers of Excellence': Library Services and the Future of the Academic Library.” College \& Research Libraries 72, no. 1: 6-8. doi.org/10.5860/0720006. 